\title{
LATE RESULTS OF BILATERAL ENDOSCOPIC SPHINCTEROTOMY IN PATIENTS WITH UPPER MOTOR NEURONE LESIONS
}

\author{
By H. J. Hachen, M.D. and R. OtT, M.D. \\ Spinal Injuires Centre, Geneva University Hospital, Switzerland
}

Abstract. Most authors presently agree that in motor neurone lesions sphincterotomy provides a reliable means of alleviating chronic retention due to detrusor-sphincter dysfunction. But, although early results may be very encouraging, one should consider that some patients are prone to fibro-sclerotic restenosis. Regular annual check-ups are therefore essential in order to avoid relevant complications.

\section{Introduction}

NowADAYs, when most paraplegic centres are in need of additional beds for the treatment of acute cases, it is becoming increasingly difficult to assure regular annual check-ups for all former patients. The persistent high rate of new casualties, low incidence of mortality and longer life expectancy are factors that contribute to this alarming situation. Many paraplegics, who are apparently faring well, have not been re-examined since they left the department two or three years ago. In the meantime, they may have developed various urological complications that have remained undiagnosed.

The purpose of this paper is to assess the late results two to three years after sphincterotomy in patients with upper motor neurone lesions and to compare the data with that obtained in the same patients during the early postoperative stage (Rossier \& Ott, I974).

In fact most reports on sphincterotomy published in recent years put emphasis upon the immediate beneficial effect on vesical outlet obstruction, whereas little information is available on long-term efficiency (Baker et al., I950; Ross et al., I967; Currie et al., I970; Malament, I972; O’Flynn, I972; Britten, I974; Rossier, I974; Madersbacher, I975).

Better understanding of the complex anatomy of the membranous urethra (Miller, 1972; Sant, I972), more accurate assessment of the underlying functional disorders responsible for chronic retention (Whiteside, 1972; Abel et al., 1975) and considerable improvement in surgical technique and postoperative care, have contributed to a much wider acceptance of sphincterotomy in most spinal injury units. However, much controversy still remains regarding the clinical and urodynamic criteria that warrant the procedure, the moment most suitable for endoscopic myotomy and the surgical technique affording the best permanent results.

\section{Patients and Methods}

Between September I970 and December I973, 36 patients with upper motor neurone lesions admitted to the Paraplegic Centre of Geneva University Hospital 


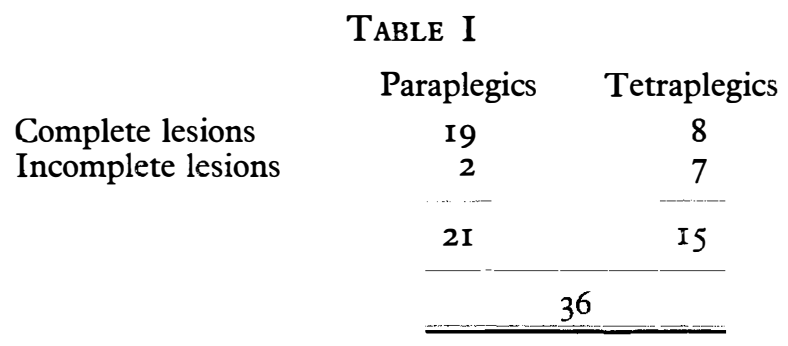

TABLE II

Bladder-neck resection

Sphincterotomy

Neck-resection + sphincterotomy
Number

5 cases

I4 cases

I 7 cases
Average age

49 years

32 years

39 years

\section{TABLE III}

Clinical and urodynamic findings among $3 \mathrm{I}$ patients selected for sphincterotomy

Residual urine repeatedly above $100 \mathrm{ml}$.

False-negative ice-water test

27

Chronic infection of the lower tract

Vesico-ureteral reflux

Reflux into vas deferens

Urethral sphincter resistance above $100 \mathrm{~cm} . \mathrm{H}_{2} \mathrm{O}$

Severe trabeculation of the bladder

Detrusor hypertrophy

Sphincter stenosis (micturition cysto-urethrography)

\section{8}

19

3

I

18

12

9

required urological endoscopic surgery for chronic retention. Table I summarises the level and type of lesion. Table II indicates the type of intervention and the average age of the respective groups.

Twenty-one patients were operated on within the first year of injury (average five to six months after admission). The remaining ten were readmissions who had shown signs of gradual decompensation of bladder function.

Endoscopic resection was carried out in a small group of five elderly patients with fibro-sclerotic changes of the bladder neck and adenomatous involvement of the prostate (a diagnosis which was subsequently confirmed by histological examination). In these patients micturition cysto-urethrograms invariably showed a closed bladder outlet, whereas sphincterometry indicated values of 75-90 cm. $\mathrm{H}_{2} \mathrm{O}$, i.e. only slightly above the normal. Among the remaining $3 \mathrm{I}$ cases, indications for sphincterotomy were mainly based upon the clinical and urodynamic criteria shown in Table III. 
TABLE IV

Urological follow-up in 23 patients 14 to 38 months after sphincterotomy

Urinary infection

Residual urine $\geqq 75$ ml.*

$14(61 \%)$

Sphincter resistance $\geqq 75 \mathrm{~cm}$. $\mathrm{H}_{2} \mathrm{O} \dagger$

Vesico-urethral reflux $\ddagger$

Bladder stones

$\star$ Differential bladder scintigraphy.

† Sphincterometry performed in infected patients only.

$\ddagger$ Not present prior to sphincterotomy.

In all $3 \mathrm{I}$ patients sphincterotomy was carried out by the same urologist using the same technique (that is, bilateral three and nine o'clock incisions with a Storz resectoscope, the cuts being approximately $6 \mathrm{~mm}$. deep and $20 \mathrm{~mm}$. long so as to secure complete section of the entire central portion of the sphincter located between the verumontanum and urogenital diaphragm). The operations were performed under rachianesthesia with $8 \mathrm{mg}$. Pontocaine in $1.5 \mathrm{ml}$. of ten per cent glucose, in order to abolish flexor and adductor spasms in both hips and to avoid sudden dysreflexia in tetraplegics. Severe bleeding, requiring compensation by transfusion, occurred in three patients (ten per cent).

Two patients complained of partial loss of erection. The early postoperative results obtained in 26 patients belonging to this group have been assessed and published by Rossier and Ott. They proved highly successful if one considers that the average residual dropped to less than $50 \mathrm{ml}$. (pre-op. I00- $150 \mathrm{ml}$.) and that sphincter resistance remained below $35 \mathrm{~cm} . \mathrm{H}_{2} \mathrm{O}$ (pre-op. above $100 \mathrm{~cm} . \mathrm{H}_{2} \mathrm{O}$ ).

\section{Follow-up}

Following bilateral sphincterotomy all but two patients in this series became permanently incontinent and required a condom-urinal. In spite of our insistence on regular bladder emptying at three-hourly intervals some patients felt that there was much overemphasis from our side and that they fared quite well without regular attempts at complete voiding.

Since last autum we have had the opportunity to re-examine 23 patients who previously underwent sphincterotomy. The average interval between the operation and first follow-up was 21 months (I4-38 months).

Table IV summarises the urological status upon readmission. Among patients with sterile urine upon readmission, radioisotope assessment of the residual indicated values varying between 10 and $50 \mathrm{ml}$.

The three patients with reflux also had a relatively high sphincter resistance $\left(75-\mathrm{IOO} \mathrm{cm} . \mathrm{H}_{2} \mathrm{O}\right)$ and infected urine. Two are presently awaiting resphincterotomy and one a circumferential bladder-neck resection.

In patients found to have sterile mid-stream urine we definitely avoid instrumentation and resort to differential bladder scanning before and after 

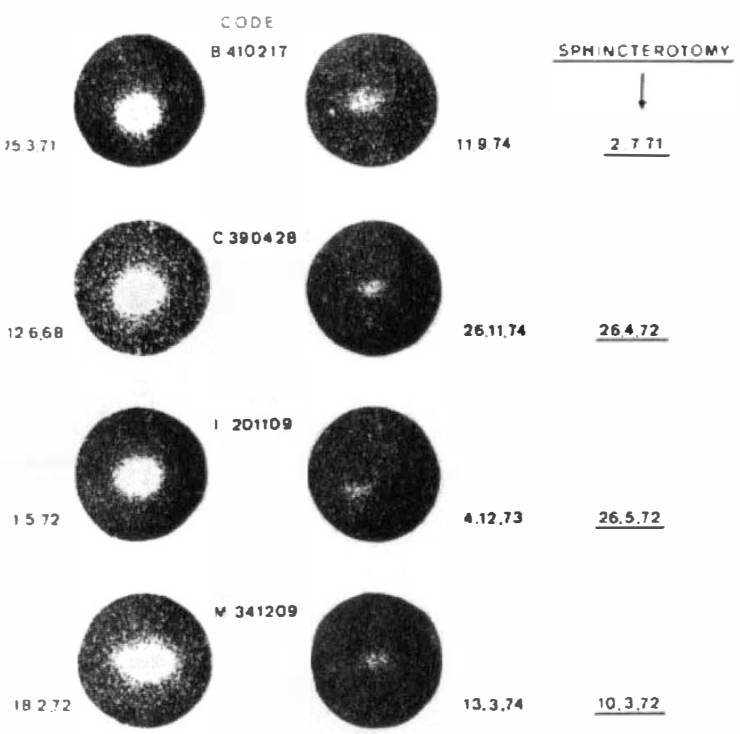

\section{5 .12}
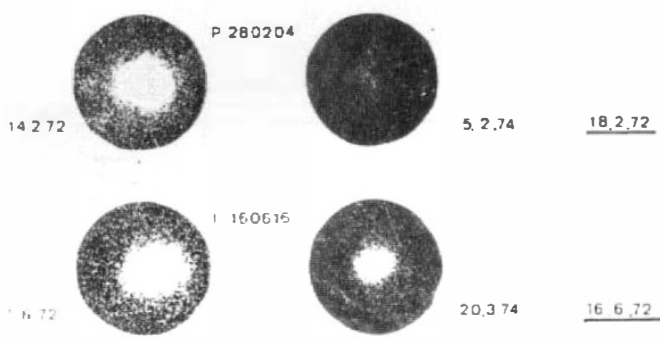

FIG. I

Before and two years after sphincterotomy.

micturition in order to evaluate the approximate volume of residual urine (fig. I).

In patients with chronic urinary infection Videoampex analysis of detrusor and sphincter activity both at rest and during micturition combined with simultaneous recording of pressure changes within the bladder and at both sphincters (fig. 2) has provided us with valuable information regarding the structure mainly responsible for functional decompensation (Whiteside, 1972; Abel et al., 1975) (fig. 3).

On the other hand, in the series under review, sphincter electromyography has been found to be of no avail in estimating the efficacy or failure of sphincterotomy (Hutch et al., I968; Donker et al., 1972).

\section{RÉSUMÉ}

Les auteurs comparent les résultats précoces et tardifs après une sphinctérotomie bilatérale par voie endoscopique pratiquée chez 31 patients atteints d'une lésion neurone moteur supérieure. Les indications opératoires furent les suivante: résidu post-mictionnel 

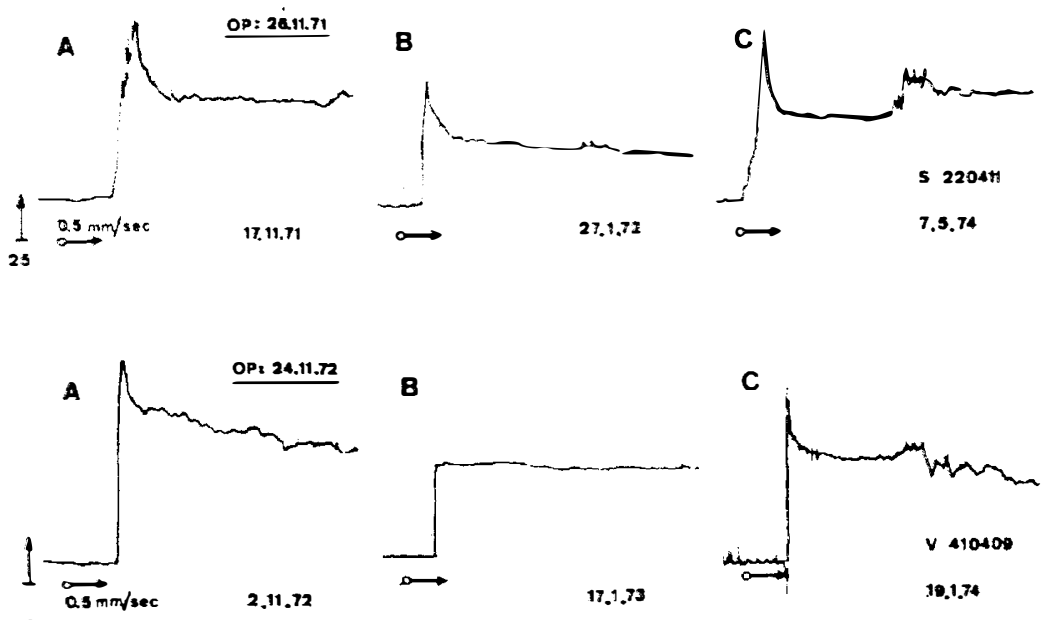

25
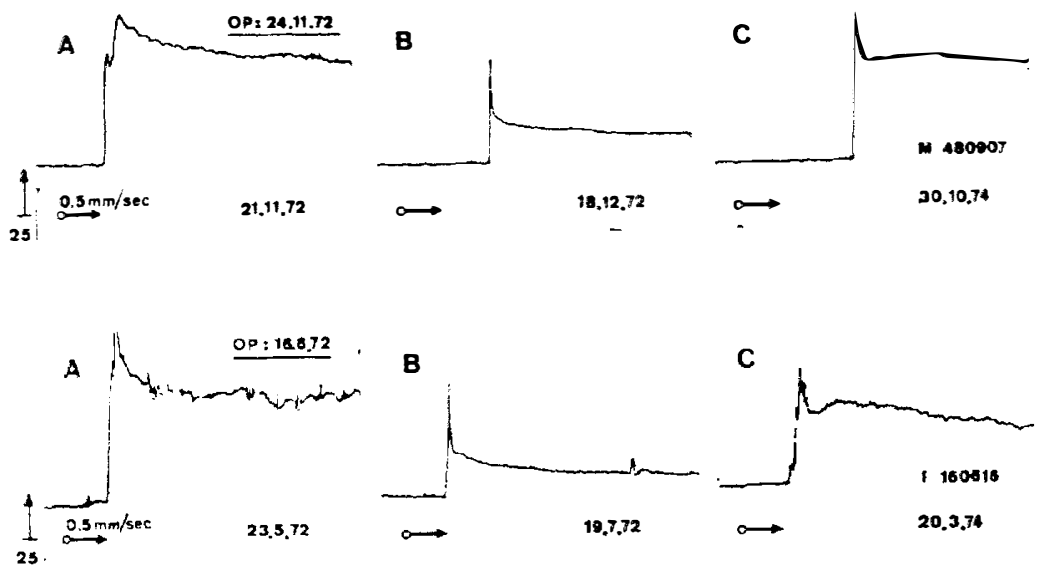

FIG. 2

Comparative sphincterometry before and after sphincterotomy.

$\geqq 100 \mathrm{ml}$. (27 cas), résistance sphinctérienne $\geqq \mathrm{I} 00 \mathrm{~cm} \cdot \mathrm{H}_{2} \mathrm{O}$ ( $\mathrm{I} 8 \mathrm{cas}$ ), reflux vésico-urétéral (trois cas). Lors du premier contrôle ( 5 mois post-op.) tant le volume résiduel que la résistance sphinctérienne furent en-dessous de 50. Un bilan tardif (pratiqué 2I mois après l'intervention) aboutit aux résultats suivants: urine stérile chez 17 patients avec un résidu post-mictionnel $<50 \mathrm{ml}$. (évalué par scintigraphie vésicale différentielle à la suite d'un néphrogramme isotopique). Urine infectée chez I4 patients; dans ce dernier groupe, une cystosphinctérométrie de contrôle objectiva une nouvelle hausse de la résistance sphinctérienne à $>75 \mathrm{~cm}$. $\mathrm{H}_{2} \mathrm{O}$ et l'urétrographie mictionnelle montra invariablement une resténose d'origine cicatricielle. Ces observations indiquent que chaque deuxième patient ayant subi une sphinctérotomie (initialement efficace) perd ultérieurement en partie l'effet bénéfique immédiat de cette intervention. Afin de prévenir l'apparition d'éventuelles complications tardives, nous préconisons un contrôle annuel de ces patients au même titre que pour les non-opérés. 


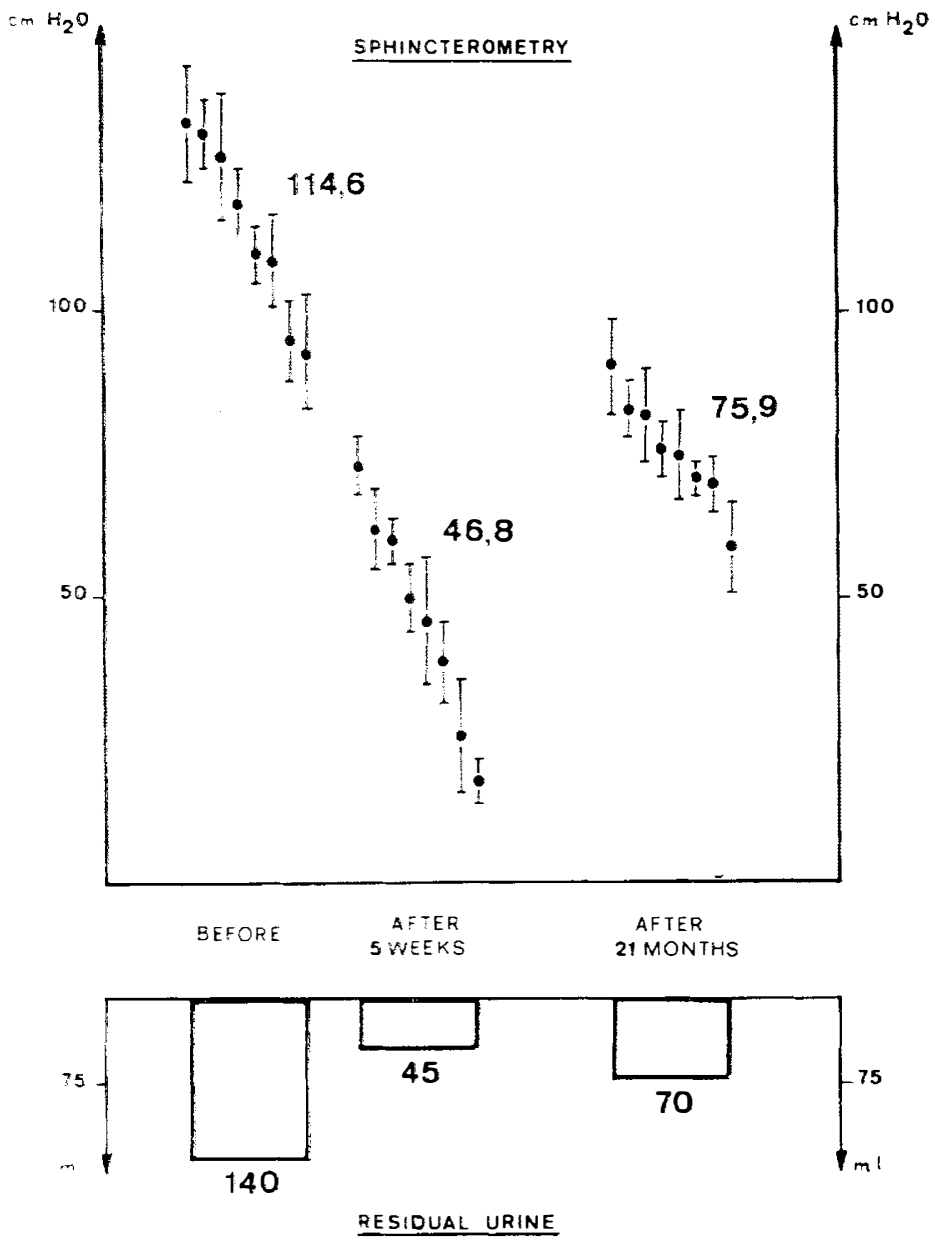

FIG. 3

Early and late effects of bilateral sphincterotomy on urethral sphincter pressure and residual urine.

\section{ZUSAMMENFASSUNG}

Die Autoren vergleichen Früh-und Spätresultate nach beidseitiger endoskopischer Sphinkterotomie an 31 querschnittgelähmten Patienten mit einer Läsion des oberen Motoneurons. Es lagen folgende Indikationen vor: Restharnvolumen konstant über $100 \mathrm{ml}$. (27 Fälle), Sphinkterwiderstand höher als IOO cm. $\mathrm{H}_{2} \mathrm{O}$ ( I8 Fälle), vesiko-ureteraler Rückfluss (Drei Fälle). Bei der ersten Nachuntersuchung (5 Monate post-op.) waren sowohl der Restharn, als auch der Sphinkterdruck unter 50. Bei einer Spätkontrolle (durchschnittlich 2I Monate post-op.) waren I7 Patienten steril, bei einem Restharnvolumen unter $50 \mathrm{ml}$. (dargestellt mittels Blasenszintigraphie im Anschluss an ein IsotopenNephrogramm). Bei I4 Patienten wurde ein Infekt festgestellt. In dieser Gruppe konnte sphinktermanometrisch ein erneuter Druckanstieg im Urethralsphinkter auf über $70 \mathrm{~cm}$. $\mathrm{H}_{2} \mathrm{O}$ nachgewiesen werden; gleichzeitig lies die Miktionsurethrographie in all den betreff- 
enden Fällen eine geringgradige fibrosklerotische Vernarbung im Operationsbereich erkennen. Diese Beobachtungen weisen darauf hin, dass selbst nach einer technisch einwandfreien Sphinkterotomie jeder zweite Patient innerhalb von zwei Jahren einen beträchtlichen Anteil des anfäglichen Operationserfolges wieder einbüsst. Regelmässige jährliche Nachkontrollen sind deshalb auch bei diesen Patienten absolut erforderlich, um eventuelle Spätkomplikationen rechtzeitig zu erfassen.

\section{REFERENCES}

Abel, B. J., Cosbie-Ross, J., Gibbon, N. O. K. \& JAmeson, R. M. (1975). Urethral pressure measurements after division of the external sphincter. Paraplegia, 13, 37-4I.

BAKER, W. J., CARNEY, J. F. \& DE ROSA, F. P. (1950). Transurethral resection for relief of urinary retention in patients with neurologic lesions. Fournal of Urology, 63, 309-3 I6.

BritTEN, D. (1974). Transurethrale Eingriffe bei der querschnittsgelähmten Blase. Urologe, 13, 93-95.

Currie, R. J., Bilbisi, A. A., Schiebler, J. C. \& Bunts, R. C. (I970). External sphincterotomy in paraplegics: technique and results. Fournal of Urology, 103, 64-68.

DeEs, J. E. (1948). Transurethral resection for neurological bladder. Fournal of Urology, 60, 907-9I4.

Donker, P. J., Ivanovici, F. \& NoACH, E. L. (1972). Analysis of the urethral pressure profile by means of electromyography and the administration of drugs. British fournal of Urology, 44, I80-193.

EmMETT, J. L. (I940). Urinary retention from imbalance of detrusor and vesical neck. Treatment by transurethral resection. Fournal of Urology, 43, 692-704.

Hutch, J. A. \& ElliotT, H. W. (1968). Electromyographic study of electrical activity in the paraurethral muscles prior to and during voiding. Fournal of Urology, 99, 759-765.

MADERSBACHER, H. \& SCOTT, B. (1975). Twelve o'clock sphincterotomy: technique, indications, results. Urol. Int. 30, 75-76.

Malament, M. (1972). External sphincterotomy in neurogenic bladder dysfunction. fournal of Urology, ro8, 554-557.

MiLleR, E. R. (I972). Bladder and urethra. Invest. Radiol. 7, 280-286.

O'FLYNN, J. D. (I972). External sphincterotomy for the relief of outlet obstruction in neurogenic bladder. Paraplegia, 10, 29-36.

Pedersen, I., Steiner, I., Sellden, U. \& Kollberg, S. (1962). Investigation of urethral sphincter in women with simulatenous electromyography and micturition urethrocystography. Acta neurol. Scand. 38, suppl. 3, I45-I 5 I.

Ross, J. C., Damanski, M. \& GibBon, N. (I958). Resection of the external urethral sphincter in the paraplegic. Fournal of Urology, 79, 742-746.

Ross, J. C., GibBon, N. O. K. \& DAMANSKI, M. (1967). Division of the external sphincter in the treatment of the neurogenic bladder. A ten-year review. British fournal of Surgery, 54, 627-628.

Rossier, A. B. \& OTT, R. (I974). Urinary manometry in spinal cord injury: a follow-up study. Value of cysto-sphincterometrography as an indication for sphincterotomy. British fournal of Urology, 46, 439-448.

SANT, G. R. (1972). The anatomy of the external striated urethral sphincter. Paraplegia, I0, I $53-156$.

WhITESIDE, C. G. (I972). Videocystographic studies with simultaneous pressure and flow recordings. Brit. Med. Bull. 28, 2 I 4-219. 